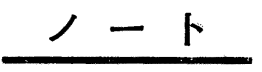

\title{
Oxygen Absorption Method for Assessing Oxidative Stability of Fats and Oils
}

\author{
Akihiko NAGAO and Megumi YamaZAKI \\ National Food Research Institute, Ministry of Agriculture, \\ Forestry and Fisheries (Yatabe, Tsukuba, Ibaraki)
}

\begin{abstract}
An oxygen absorption method was applicated for the evaluation of oxidative stability of fats and oils. The amount of oxygen absorbed by fats and oils was measured with a Warburg manometer at $70^{\circ} \mathrm{C}$. The induction periods, that is, the time required for decreasing the pressure in the flask by 20 $\mathrm{mmHg}$, showed excellent correlation with those obtained by an active oxygen method (A.O.M.) and the almost same precision as A.O.M. and weighing method.
\end{abstract}

\section{Introduction}

An active oxygen method (A.O.M.) ${ }^{1)}$, weigh= ing method ${ }^{2) \sim 4}$, and organoleptic tests ${ }^{3), 4}$ are ordinarily used for assessing oxidative stability of fats and oils. These methods are time-con= suming or complicated. The oxygen absorption methods have been applicated to the studies of autoxidation of fats and oils. There have been, however, few reports ${ }^{5), 6}$ on the evaluation of oxidative stability. The possibility of an oxyo gen absorption method with a Warburg mano= meter for assessing oxidative stability was inves= tigated here, since this method seemed to be simple and rapid and further the apparatus was easily obtainable.

\section{Materials and Methods}

Fresh fats and oils: lard, safflower oil, soy= bean oil, rapeseed oil, and rice-bran oil were obtained from Tsukishima Food Co., Ltd.,

Oxygen absorption was measured with a War= burg manometer (Mitamura Riken Kogyo Co., Ltd.). Mercury was used in the place of Bro=

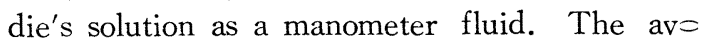
erage volume of the flasks was about $25.8 \mathrm{ml}$.

About $100 \mathrm{mg}( \pm 5 \mathrm{mg}$ ) of fats and oils was spread on the bottom of main compartment in the flask. The flasks were attached to the manometer and then the air over the sample was fully replaced with oxygen. To avoid the effect of light on the autoxidation, the flasks were covered with aluminium foil. They were incubated in a water bath controlled at $70 \pm$ $0.1^{\circ} \mathrm{C}$. The decrease of pressure in the flask was measured with manometer at intervals.

Weighing method was carried out at $60^{\circ} \mathrm{C}$ and the induction period was estimated from the time required for increasing the weight of sam= ple $(1 \mathrm{~g})$ by $10 \mathrm{mg}$.

\section{Results and Discussions}

\subsection{Experimental conditions}

Brodie's solution was ordinarily used as a ma $=$ nometer fluid. However, the amount of oxy= gen absorbed by the sample was too large to measure the induction period with Brodie's so $=$ lution under the conditions as above. The in $=$ cubation temperature controlled at $70 \pm 0.1^{\circ} \mathrm{C}$ resulted in the disturbance of level of Brodie's solution. Therefore, mercury was used as a ma= nometer fluid. The test time could be short $=$ ened at the high temperature, but it became difficult to control the water bath at such tem = perature precisely. The incubation temperature was set at $70^{\circ} \mathrm{C}$.

Fig.-1 shows the decrease of pressure in the flask caused by the oxygen absorption of saf $=$ flower oil. The induction period was shortened when the air over the sample was replaced with oxygen (Curve 1 ). The time required for decreasing pressure by $20 \mathrm{mmHg}$ was $40 \mathrm{~h}$ under oxygen and this value was about twothirds of that required under the air. The air 


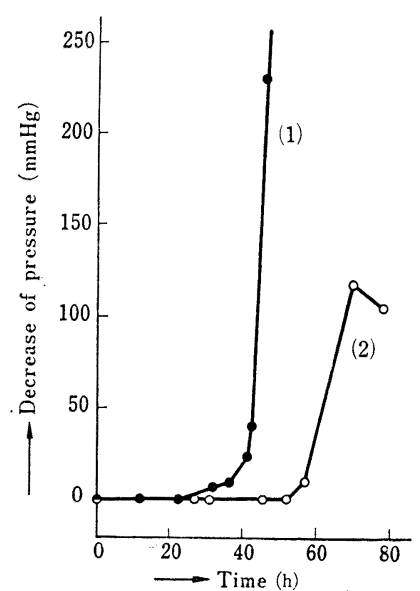

(1): under oxygen (2): under the air

Fig.-1 Oxygen absorption of safflower oil.

over the sample was replaced with oxygen in the following experiments.

\section{$3 \cdot 2$ Oxygen absorption curves}

Characteristics of various fats and oils used in this experiment are shown in Table-1 and fatty acid compositions in Table-2.

Table-1 Characteristics of fats and oils.

\begin{tabular}{l|ccc}
\hline Fats and oils & POV & AV & IV \\
\hline Lard & 0.41 & 0.13 & 64.9 \\
Safflower & 1.13 & 0.23 & 143.4 \\
Rapeseed & 0.12 & 0.16 & 117.8 \\
Soybean & 0.84 & 0.11 & 142.3 \\
Rice-bran & 1.05 & 0.28 & 107.0 \\
\hline
\end{tabular}

Table-2 Fatty acid compositions of fats and oils.

\begin{tabular}{l|rrrrrrrr}
\hline \multirow{2}{*}{ Fats and oils } & \multicolumn{5}{|c}{ Fatty acids (\%) } \\
\cline { 2 - 7 } & $14: 0$ & $16: 0$ & $16: 1$ & $18: 0$ & $18: 1$ & $18: 2$ & $18: 3$ \\
\hline Lard & 1.7 & 24.7 & 4.0 & 11.9 & 45.8 & 10.5 & 1.5 \\
Safflower & 0 & 8.3 & 0 & 2.6 & 13.0 & 74.9 & 1.2 \\
Rapeseed & 0 & 3.8 & 0 & 1.8 & 62.4 & 20.9 & 11.1 \\
Soybean & 0 & 11.9 & 0 & 4.2 & 25.2 & 52.0 & 6.9 \\
Rice-bran & 0 & 19.5 & 0 & 1.8 & 41.5 & 35.0 & 1.9 \\
\hline
\end{tabular}

Fig. -2 shows the decrease of pressure with the oxidation of fats and oils at $70^{\circ} \mathrm{C}$. Little oxygen absorption was obserbed during the in duction period followed by very rapid decrease of pressure. The time required for decreasing pressure by $20 \mathrm{mmHg}$ under the conditions as above was used as the index of oxidative sta $=$ bility. It corresponded to oxygen absorption of

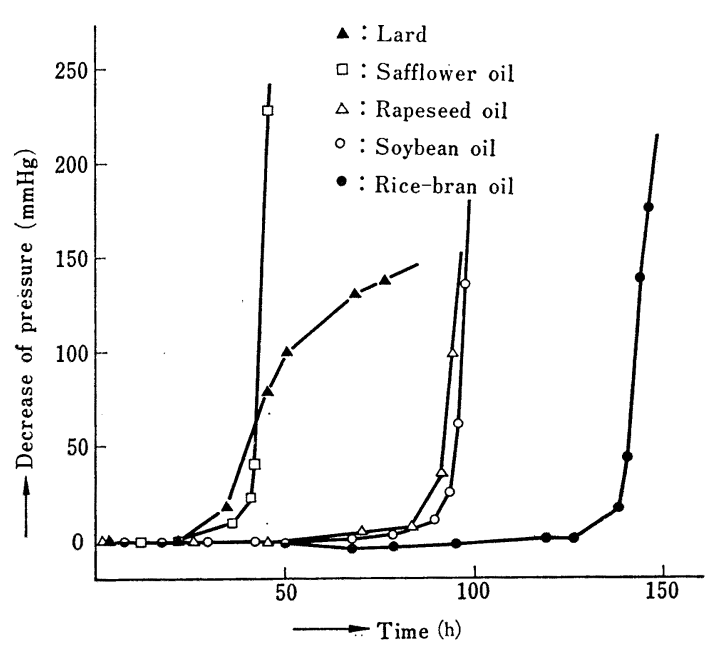

Fig.-2 Oxygen absorption curves.

about $0.54 \mathrm{ml}$ on the assumption that gravity of sample and Bunsen coefficient ${ }^{7), 8)}$ were 0.9 and 0.1 , respectively.

\subsection{Comparison of three methods}

The values obtained by three methods were compared using various fats and oils (Table-3). The values of rice-bran oil were $22 \mathrm{~h}$ by A.O. M., $21.4 \mathrm{~d}$ by weighing method and $149 \mathrm{~h}$ by the oxygen absorption method (O.A.M.). The time required for assessing oxidative stability could be shortened to about one-thirds of that required in weighing method.

Table-3 Comparison among the values by three methods.

\begin{tabular}{l|r|c|c}
\hline \multicolumn{1}{c|}{ Fats and oils } & $\begin{array}{c}\text { A.O.M. } \\
(\mathrm{h})\end{array}$ & $\begin{array}{c}\text { Weighing } \\
\operatorname{method}(\mathrm{d})\end{array}$ & $\begin{array}{c}\text { O.A.M. } \\
\text { (h) }\end{array}$ \\
\hline Lard & 7.4 & 5.6 & 35.0 \\
Safflower & 7.7 & 8.3 & 40.0 \\
Soybean-Safflower* & 11.6 & 12.1 & 66.0 \\
Rapeseed & 15.5 & 11.4 & 88.6 \\
Soybean & 15.9 & 15.3 & 93.0 \\
Soybean-Rice-bran* & 17.8 & 17.2 & 114.0 \\
Rice-bran & 22.0 & 21.4 & 149.0 \\
\hline
\end{tabular}

* Mixture of two oils by the ratio of $1: 1(\mathrm{wt} / \mathrm{wt})$

Fig. -3 shows the correlation between these methods, and it became apparent that O.A.M. showed excellent correlation with A.O.M. $(r=$ 0.995). Table- 4 shows the values of rapeseed oil obtained in several experiments. The ratio of standard deviation to average was smaller in O.A.M. than in weighing method.

These results indicated that the oxygen $a b=$ 


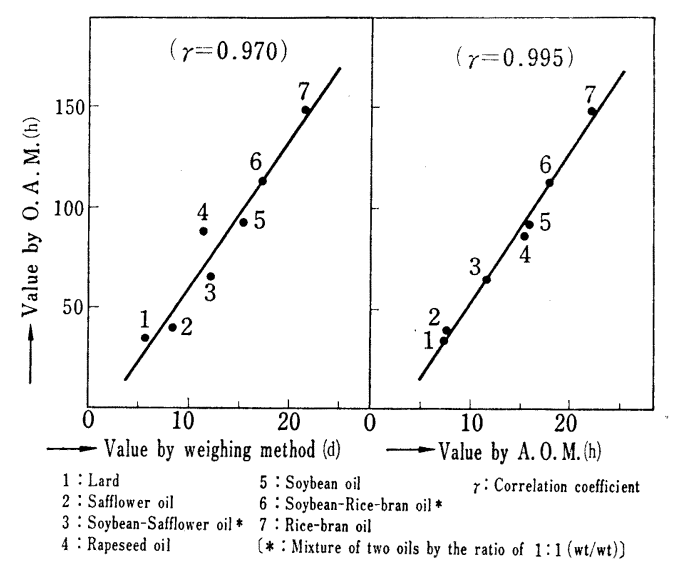

Fig.-3 Correlation between three methods.

Table-4 Values of rapeseed oil by three methods.

\begin{tabular}{c|c|c|c}
\hline $\begin{array}{c}\text { Number of } \\
\text { experiment }\end{array}$ & $\begin{array}{c}\text { A.O.M. } \\
(\mathrm{h})\end{array}$ & $\begin{array}{c}\text { Weighing } \\
\operatorname{method}(\mathrm{d})\end{array}$ & $\begin{array}{c}\text { O.A.M. } \\
(\mathrm{h})\end{array}$ \\
\hline 1 & 16.0 & 11.4 & 86 \\
2 & 15.8 & 11.7 & 89 \\
3 & 15.7 & 10.6 & 88 \\
4 & 15.4 & 11.6 & 89 \\
5 & 15.4 & 11.8 & 91 \\
6 & 15.4 & 11.7 & - \\
7 & 15.2 & 11.1 & - \\
8 & 15.4 & 11.7 & - \\
\hline Average (x) & 15.5 & 11.5 & 89 \\
Standard & 0.24 & 0.37 & 1.9 \\
Deviation (s) & & & \\
(s/x) 100 & 1.5 & 3.2 & 2.1 \\
\hline
\end{tabular}

sorption method investigated in this experiment with a commercial Warburg manometer showed excellent correlation with A.O.M. and the almost same precision as A.O.M. and weighing method. Furthermore, the amount of sample required in O.A.M. was very small $(100 \mathrm{mg})$ compared with A.O.M. (20 ml) and weighing method $(1 \mathrm{~g})$.
O.A.M. was the most simple of these methods and not so time-consuming as weighing method.

Further improvement of the apparatus, for example, incubator and manometer, would be expected to shorten the test time and to record the oxygen absorption automatically.

\section{Acknowledgment}

The authors are grateful to Tsukishima Food Co., Ltd. for a gift of fats and oils.

(Receivel April 22, 1981)

\section{References}

1) A.O.C.S. Official method $\mathrm{Cd} 12-57$.

2) H.S. Olcott and E. Einset, J. Am. Oil Chem. Soc., 35, 161(1958).

3) G. Kajimoto, K. Horikawa, M. Ota, T. Naka $=$ yama, S. Yoneyama, J. Hirano, E. Yuki, M. Fujiwara, S. Chiba, and S. Masuyama, Yuka= gaku, 25, 525 (1976).

4) G. Kajimoto, K. Nakayama, K. Horikawa, H. Morishima, S. Yoneyama, S. Ishida, E. Yuki, M. Fujiwara, S. Chiba, and S. Masuyama, Yu= kagaku, 27, 38 (1978).

5) I.R. Hunter, J. Am. Oil Chem. Soc., 28, 160 (1951).

6) E.B. Lancaster, E.D. Bintner, and R.E. Beal, J.Am. Oil Chem. Soc., 33, 36 (1955).

7) R. Battino, F.D. Evans, and W.F. Danforth, J. Am. Oil Chem. Soc., 45, 830 (1968).

8) P.J. Ke and R.G. Ackman, J. Am. Oil Chem. Soc., 50, 429 (1973).

\section{酸素吸収法による油脂の酸化安定性試験法}

$$
\begin{gathered}
\text { 長尾 昭彦・山崎 恵 } \\
\text { 農林水産省食品総合研究所 } \\
\text { (茨城県筑波郡谷田部町観音台 2-1-2) }
\end{gathered}
$$

酸素吸収法による油脂の酸化安定性試験法を検討し た。 $70^{\circ} \mathrm{C}$ で油脂に吸収される酸素量をワールブルグ検 圧計を用い測定した。フラスコ内の圧力が $20 \mathrm{mmHg}$ だ け減少するのに要する時間を誘導期の長さとした。本法 によって得た值は, A.O.M. の值と極めてよい相関性を 示し，また A.O.M. や重量法と同程度の精度を示した。 